\title{
One-pot synthesis of new derivatives of 3,4-dihydropyrimidinone, and substituted imidazolin-2-ones
}

\author{
N. V. Chechina, V. V. Zubar, I. V. Omelchenko and N. N. Kolos* \\ Department of Organic Chemistry, V. N. Karazin Kharkiv National University, \\ Svoboda sq. 4, 61022 Kharkiv, Ukraine \\ E-mail:kolos_n@mail.ru
}

DOI: http://dx.doi.org/10.3998/ark.5550190.p009.324

\begin{abstract}
Three-component condensation of arylglyoxals, acetylacetone and urea in EtOH in the presence of small amounts of HOAc gives rise to 5-acetyl-4-aroyl-6-methyl-3,4-dihydropyrimidinones or 5-aryl-1,3-dihydro-2H-imidazol-2-ones containing an acetylacetone fragment in position 4. $(1 \mathrm{H}$ Pyrazol-4-yl)-1,3-dihydro-2H-imidazol-2-one derivatives were obtained via the reaction of the latter compounds with hydrazine. Doubt is cast upon an earlier report of the formation of pyrimido-pyridazines by condensation of hydrazines with 5-acetyl-4-aroyldihydropyrimidinones.
\end{abstract}

Keywords: Dihydropyrimidin-2-ones, imidazoline-2-ones derivatives, one-pot multicomponent reaction

\section{Introduction}

Functionalized 3,4-dihydropyrimidin-2-ones are important physiologically active compounds and they are widely used as blockers of calcium channels, $\alpha_{1}-1$-a-antagonists, antihypertensive medications, inhibitors of transmitters of fatty acids and mitotic kinesin inhibitors. ${ }^{1-5}$ One of the most general approaches to the synthesis of 3,4-dihydropyrimidin-2-ones is a multicomponent Biginelli reaction ${ }^{6}$ which includes a condensation of an aldehyde, a urea or a thiourea and 1,3dicarbonyl compounds. ${ }^{7-9}$ Recently there have been many reports of improved procedures with new catalysts in this reaction. ${ }^{10-18}$ However, three-component reactions similar to the Biginelli condensation, in which one reagent is replaced by another one (arylaldehydes are replaced by arylglyoxals) have seldom been described. Relevant is an article by Iranian chemists, ${ }^{19}$ in which the synthesis of 3,4-dihydropyrimidin-2-ones (1) in a three-component condensation of phenylglyoxal hydrate, urea and acetylacetone or ethyl acetoacetate is reported. At the same time these authors isolated imidazolin-2-ones (2) when dimethylurea was used with Lewis acid catalysts $\left(\mathrm{AlCl}_{3}: \mathrm{ZnCl}_{2}\right.$ in the ratio 1:3). More recently an article was published in which a 
number of 3,4-dihydropyrimidin-2-one derivatives in a similar condensation in the presence of tungstate sulfuric $\operatorname{acid}^{20}$ or molybdate sulfuric acid ${ }^{21,22}$ were described. It is our contention that these products were misidentified.
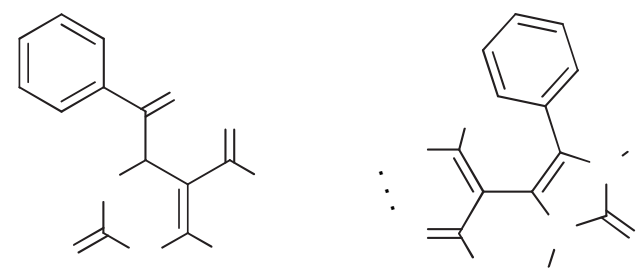

Figure 1. The structures obtained in reactions of arylglyoxal, ureas and acetylacetone or acetoacetic ester.

Since our group is also researching related multicomponent reactions, we here present our experimental data which demonstrate that the authors of ref. 20-22 isolated derivatives of imidazolin-2-ones in the course of the reaction in question, mistakenly identifying them as 3,4dihydropyrimidin-2-one derivatives.

\section{Results and Discussion}

We should first of all point out that the three-component condensation involving arylglyoxal hydrates does not occur as easily as the well-known Biginelli reaction. ${ }^{6,7}$ The experimental conditions were widely varied in order to optimize the yields of the 3,4-dihydropyrimidin-2-one derivatives. The reactions were carried out in acetic acid, EtOH in the presence of a catalytic amount of $\mathrm{HCl}$ or $\mathrm{HOAc}, \mathrm{DMF}$, and solvent-free. Also we varied the catalysts: $\beta$-cyclodextrin, L-proline, $\mathrm{FeCl}_{3}$ (Table 1). When the reaction was carried out in acetic acid, the yield of pyrimidin-2-one (the Biginelli product) amounted to 25\%, and 5-phenylimidazol-2-one was the main product of the reaction. It was also the main product when we carried out the reaction in an $\mathrm{EtOH} / \mathrm{HCl}$ system, and also in the cases 4, 5. Heating the initial reagents in DMF led to a resinous residue. The best results were obtained when the reaction was carried out in EtOH with small amounts of $\mathrm{HOAc}$, or i-PrOH (with $\mathrm{FeCl}_{3}$ as a catalyst), or solvent-free. However, we obtained byproducts in the last two cases: imidazolone 7a (example 7) and product of addition 9a (example 9) respectively. Compound 9a ( $\mathrm{Ph}$ instead of $4-\mathrm{BrC}_{6} \mathrm{H}_{4}$, scheme 2) was identified by TLS. Earlier this product was isolated by us in a step-by-step process of a similar synthesis of adduct 9c (see Experimental section). 
Table 1. Reactions between 2,4-pentanedione (3), arylglyoxal (4a), and urea (5a)

\begin{tabular}{ccccc}
\hline Entry & Solvent & Catalyst & Time (min) & $\begin{array}{c}\text { Product (yield } \\
\%)\end{array}$ \\
\hline 1 & HOAc & - & 60 & $\mathbf{6 a}(25)+45^{a}$ \\
2 & $\mathrm{EtOH}$ & - & 120 & $\mathbf{6 a}(47)+20^{a}$ \\
3 & $\mathrm{EtOH}$ & $\mathrm{HCl}$ & 90 & $80^{a}$ \\
4 & $\mathrm{EtOH}$ & $\beta-\mathrm{Cyclodextrin}$ & 120 & $60^{a}$ \\
5 & $\mathrm{EtOH}$ & $\mathrm{L}-$ proline & 120 & $70^{a}$ \\
6 & $\mathrm{EtOH}$ & $\mathrm{HOAc}$ & 120 & $\mathbf{6 a}(60)$ \\
7 & $\mathrm{i}-\mathrm{PrOH}$ & $\mathrm{FeCl}_{3}$ & 180 & $\mathbf{6 a}(32)+7 \mathbf{a}(65)$ \\
8 & $\mathrm{DMF}$ & - & 60 & resin \\
9 & - & - & 180 & $\mathbf{6 a}+\mathbf{9 a}(82)^{b}$ \\
\hline
\end{tabular}

${ }^{a}$ The yields of 5-phenylimidazolidine-2,4-dione; ${ }^{b}$ The total yields of the products.

So the multicomponent condensation of arylglyoxals 4a-g, 2,4-pentanedione $\mathbf{3}$ and urea 5a,b was carried out by heating for three hours in the presence of a catalytic amount of acetic acid. As a result either 4-aroyl-5-acetyl-6-methylpyrimidines 6a-d or imidazolin-2-ones 7b-d were obtained from the reaction mixture. As we can see from the experiment, the products 7a-e were synthesized in lower yields.
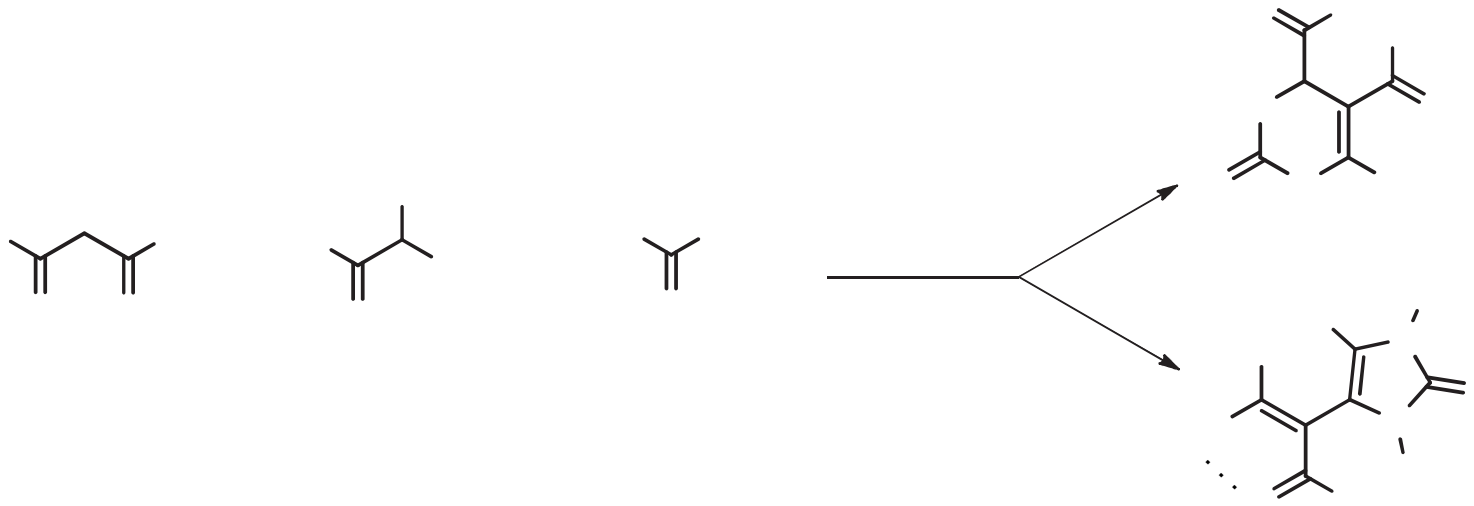

4 a $\mathrm{R}=\mathrm{Ph}, \mathbf{b} \mathrm{R}=4-\mathrm{C}_{2} \mathrm{H}_{5} \mathrm{C}_{6} \mathrm{H}_{4}$, c $\mathrm{R}=4-\mathrm{BrC}_{6} \mathrm{H}_{4}, \mathbf{d} \mathrm{R}=4-\mathrm{FC}_{6} \mathrm{H}_{4}$, e $\mathrm{R}=3-\mathrm{FC}_{6} \mathrm{H}_{4}, \mathbf{f} \mathrm{R}=4-$ $\mathrm{O}_{2} \mathrm{NC}_{6} \mathrm{H}_{4}, \mathbf{g R}=\mathrm{Me} ; 5$ a $\mathrm{R}^{1}=\mathrm{H}, \mathbf{b} \mathrm{R}^{1}=\mathrm{Me} ; 6$ a $\mathrm{R}=\mathrm{Ph}, \mathbf{b} \mathrm{R}=4-\mathrm{C}_{2} \mathrm{H}_{5} \mathrm{C}_{6} \mathrm{H}_{4}, \mathbf{c} \mathrm{R}=4-\mathrm{BrC}_{6} \mathrm{H}_{4}$, d $\mathrm{R}=4-\mathrm{FC}_{6} \mathrm{H}_{4} ; 7 \mathbf{a}-\mathbf{d} \mathrm{R}^{1}=\mathrm{H}, \mathbf{a} \mathrm{R}=\mathrm{Ph},{ }^{*} \mathbf{b} \mathrm{R}=4-\mathrm{O}_{2} \mathrm{NC}_{6} \mathrm{H}_{4}, \mathbf{c} \mathrm{R}=3-\mathrm{FC}_{6} \mathrm{H}_{4}, \mathbf{d} \mathrm{R}=\mathrm{Me}, 7 \mathbf{e} \mathrm{R}^{1}=$ $\mathrm{Me}, \mathrm{R}=4-\mathrm{FC}_{6} \mathrm{H}_{4} . \quad$ *Obtained in $\mathrm{i}-\mathrm{PrOH} / \mathrm{FeCl}_{3}$.

Scheme 1. Synthesis of products 6a-d and 7a-e.

The identification of these products presented no difficulties. The following signals are present in the NMR ${ }^{1} \mathrm{H}$ spectra of products 6a-d: methyl and acetyl group singlets with three proton intensity, a doublet of the methyne proton, a widened singlet of the proton of the imino 
group in position 3 among the signals of the aromatic protons, and a singlet of the enamine proton at approximately $9.2 \mathrm{ppm}$. For imidazolones 7a-e the following signals are characteristic: the singlet of six protons of the methyl groups of acetylacetone, the singlets of the protons of two imino groups at around 10.5-10.8 ppm and also an upfield singlet of the enol proton of the acetylacetone fragment (16.7-16.9 ppm). We have found differences in the mass-spectra of indicated compounds. There are molecular ion peaks with an intensity lower than $10 \%$ and peak $\left(\mathrm{M}^{+}-\mathrm{ArCO}\right)$ is the most intense in the spectra of compounds $\mathbf{6 a}, \mathbf{b}$. This fragmentation is not characteristic for the mass-spectra of imidazolones $7 \mathbf{b}$. The typical NMR ${ }^{1} \mathrm{H}$ spectra of products of type $\mathbf{6}$ and 7 are given in Figs 1 and 2.

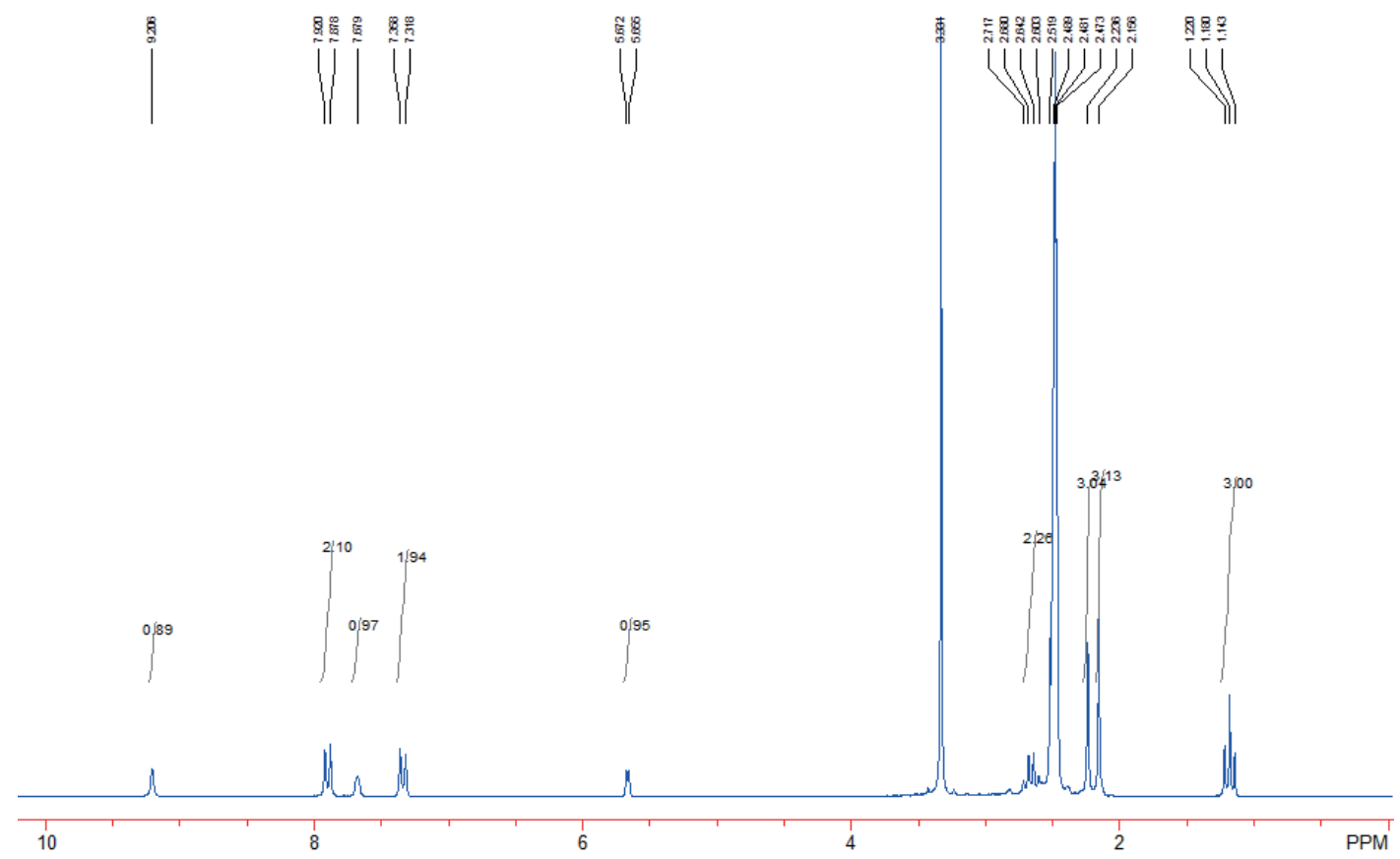

Figure 2. ${ }^{1} \mathrm{H}$ NMR spectrum of compound $\mathbf{6 b}$.

In the ${ }^{1} \mathrm{H}$ NMR spectra of the compounds described in paper 20,21 authors have ignored the fact that the shifts of the protons of the methyl and acetyl groups of pyrimidin-2-ones 6 can't be identical and do not form singlet of six protons. Furthermore, signals of imino groups of the compounds are different in nature (enamine and amide protons), thus their chemical shifts should be significantly different. At the same time, the chemical shifts of amide protons of imidazolone2-ones 7 must have similar values. Therefore, our comparison of the spectral data and Karamis' results ${ }^{20,21}$ indicates about obtaining of (Z)-4-(2-hydroxy-4-oxopent-2-en-3-yl)-5-aryl-1,3dihydro-2H-imidazol-2-ones 7 by authors of ref. 20,21.

In the reaction of $p$-fluorophenylglyoxal $\mathbf{4 d}$ with urea $\mathbf{5 b}$ only imidazolone $\mathbf{7 e}$ was obtained, although it is known that $\mathrm{N}(1)$-substituted 3,4-dihydropyrimidin-2-ones are formed in the condensation of $N$-alkylureas with aldehydes. ${ }^{23}$ However, in other cases it is quite difficult to predict the formation of six- or five-membered rings. 


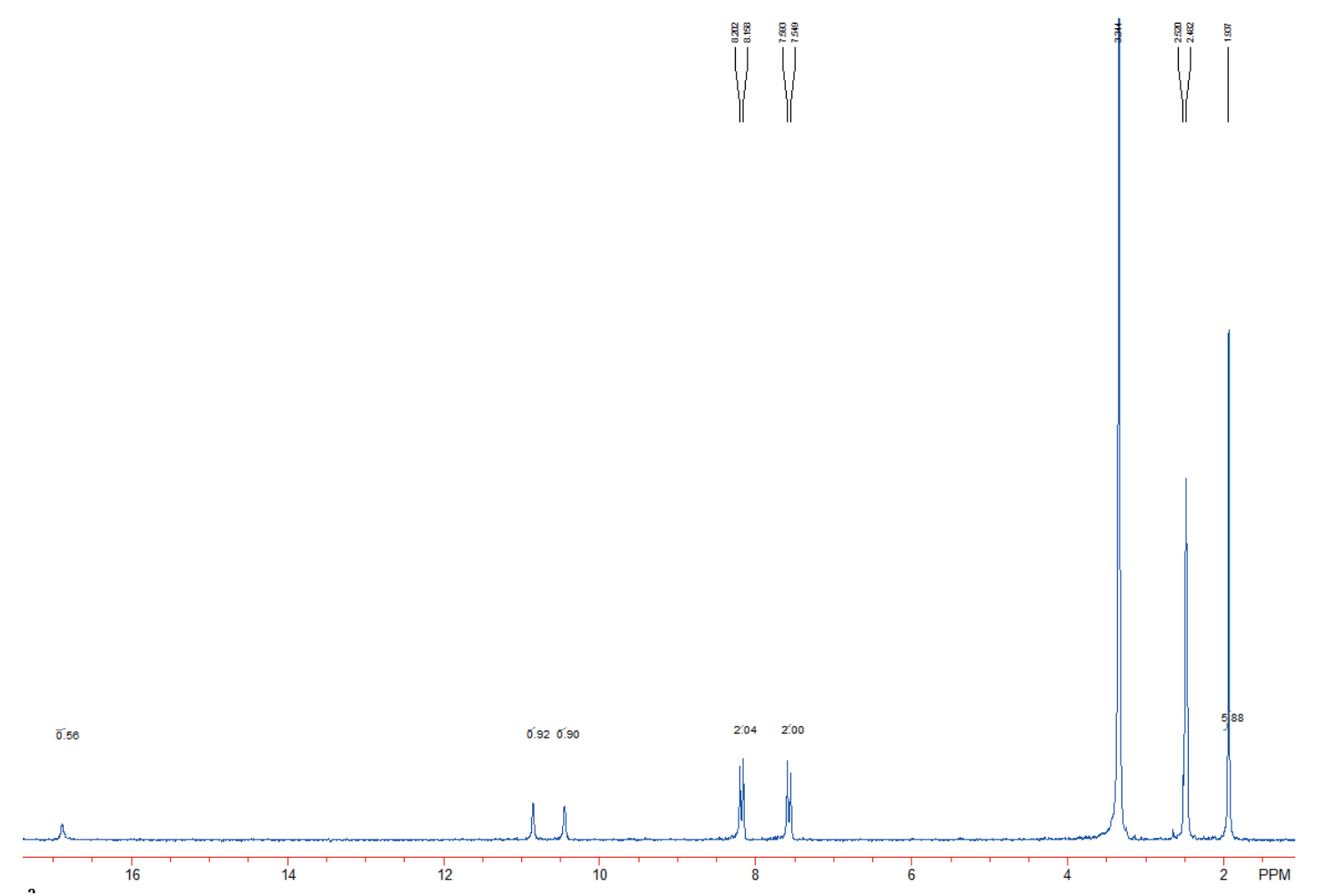

Figure 3. ${ }^{1} \mathrm{H}$ NMR spectrum of compound $7 \mathbf{b}$.

Additionally, the structure of $\mathbf{6 b}$ compound was confirmed by X-ray diffraction study (Figure 4).

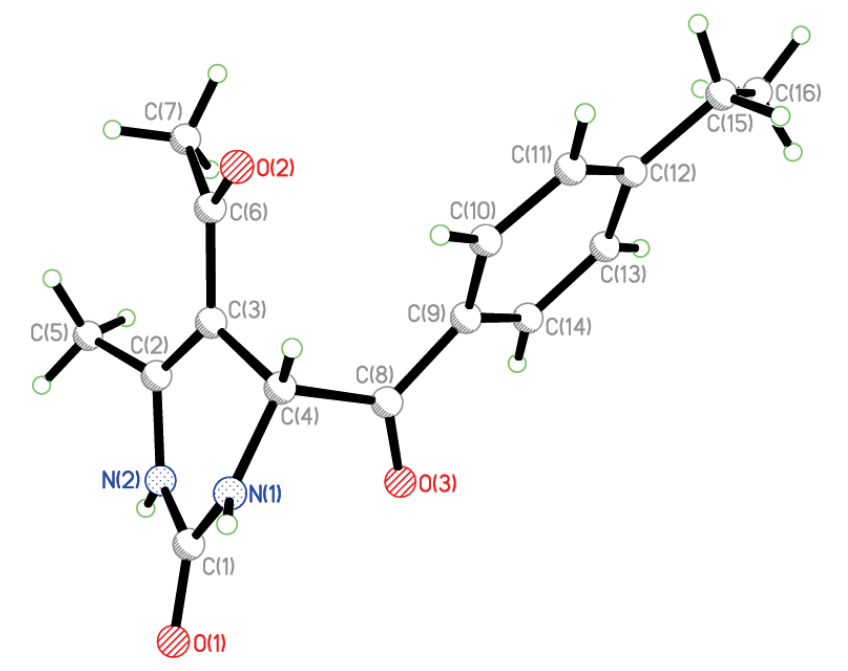

Figure 4. Molecular structure of $\mathbf{6 b}$ according to the X-ray diffraction data. 
Our experimental data show that donor substituents in the arylglyoxal fragment contribute to the formation of type 6 compounds, while acceptor substituents lead to five-membered rings. Despite the fact that the carbonyl activity of arylglyoxals $\mathbf{4 d}$ and $\mathbf{4 e}$ differs only slightly, only product $\mathbf{7 c}$ was isolated in the latter case. In the reaction of methylglyoxal $\mathbf{4 g}$ imidazolone $\mathbf{7 d}$ was also obtained.

We carried out step-by-step syntheses of products 6 and 7, as shown in Scheme 2.

3<smiles>CC(C)(O)C(=O)c1ccc(Br)cc1</smiles><smiles>OCCO</smiles>
$4 c$<smiles>CCOC(=O)COC(C)=O</smiles>

EtOH, HOAc<smiles>CC(=O)C1=C(C)NC(=O)NC1C(=O)c1ccc(Br)cc1</smiles>

$6 c$<smiles></smiles>

Scheme 2. Step-by-step synthesis of products $\mathbf{6 c}$ and $\mathbf{7 b}$.

Phenacylidene derivative 8c was obtained after reflux of diketone 3 with glyoxal $4 \mathbf{c}$ in EtOH. The following reflux of $\mathbf{8 c}$ with urea in $\mathrm{EtOH}$ in the presence of small amounts of HOAc led to adduct 9c. This last was further transformed in target pyrimidin-2-one 6c. The cyclization of such a Michael $\beta$-adduct can occur via the aroyl fragment (as the nitro-substituted 9b), as well which leads to imidazolin-2-one $\mathbf{7 b}$.

It is likely that the higher carbonyl activity of the aroyl group (or the acetyl group in glyoxal 4g) contributes to its intramolecular cyclocondensation with the formation of a five-membered ring. The acetyl group of 2,4-pentanedione undergoes cyclization in the case of donor substituents, forming 3,4-dihydropyrimidin-2-one derivatives. We note that acceptor substituents additionally stabilize the enol form of the acetylacetone fragment via the system of conjugated 
bonds. As mentioned earlier, carrying out the reaction in i-PrOH in the presence of $\mathrm{FeCl}_{3}$ is accompanied by the formation of compounds $6 \mathbf{a}$ and $7 \mathbf{a}$ (in ratio 1:2). This experimental fact can be explained by the formation of a complex of the Lewis acid with the enol form of acetylacetone, which promotes cyclization via the benzoyl fragment.

The presence of a 1,3-dicarbonyl fragment in products 7a-d makes them convenient scaffolds for the synthesis of five-membered heterocycles. So pyrazoles $\mathbf{1 0 a}, \mathbf{b}$ were obtained in the reaction of products $\mathbf{7 b}, \mathbf{d}$ with hydrazine in $\mathrm{EtOH}$. The structures of the target compounds were confirmed by spectral data.

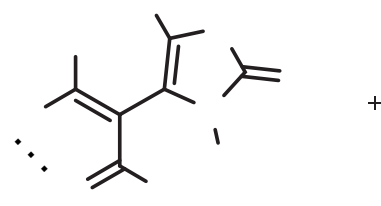

$7 b, d$

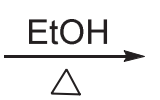

10 a $\mathrm{R}=4-\mathrm{NO}_{2} \mathrm{C}_{6} \mathrm{H}_{4}, \mathbf{b} \mathrm{R}=\mathrm{Me}$.

Scheme 3. Synthesis of products $\mathbf{1 0 a}, \mathbf{b}$.
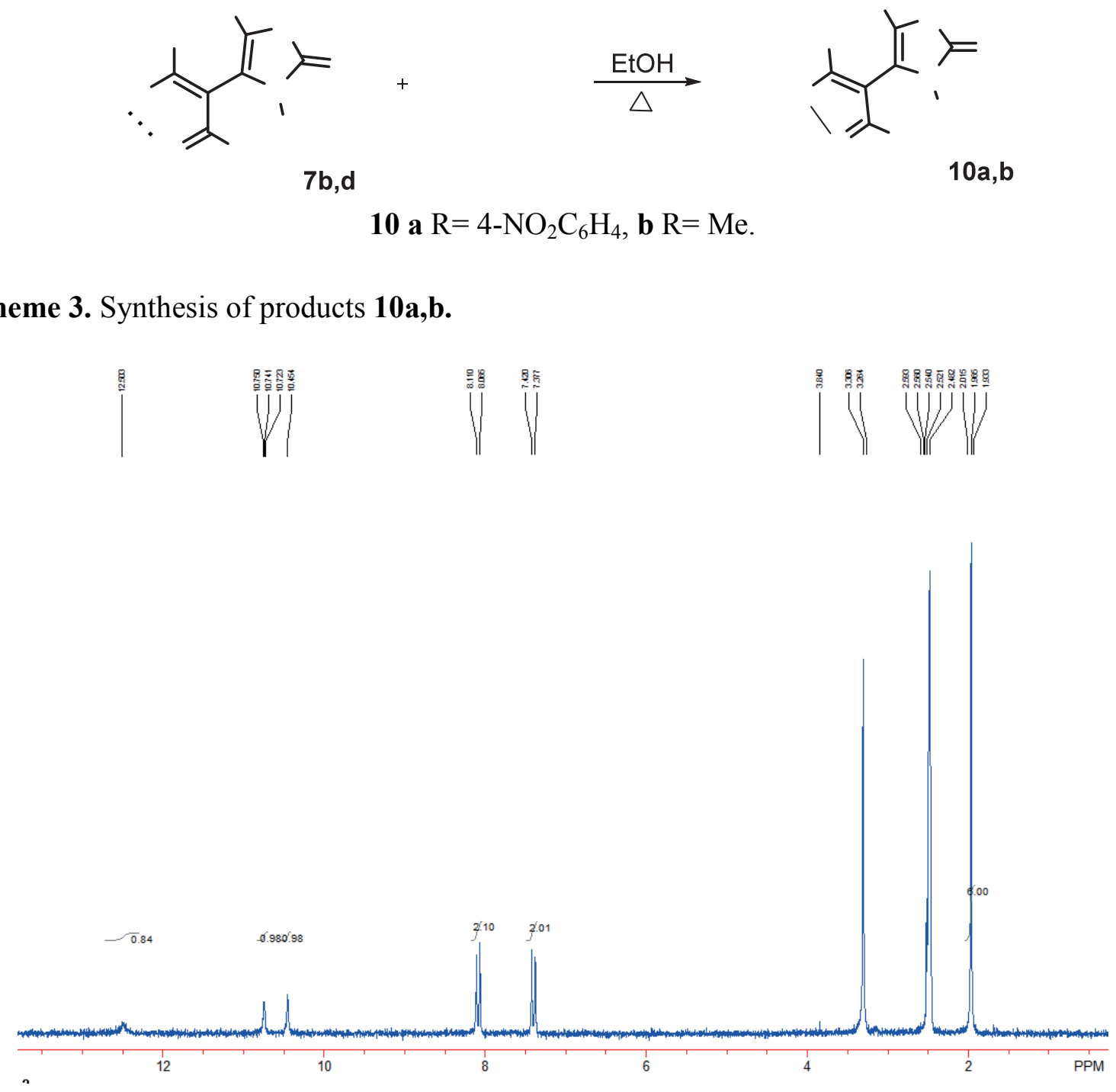

$10 \mathrm{a}, \mathrm{b}$

\section{Scheme 3. Synthesis of products 10a, b.}

Figure 4. ${ }^{1} \mathrm{H}$ NMR spectrum of compound $\mathbf{1 0 b}$. 


\section{Conclusions}

We can conclude that the pyrimido[4,5- $d]$ pyridazines as the products of condensation of 5acetyl-4-aroyl-6-methyl-3,4-dihydropyrimidin-2 $(1 H)$-one with hydrazine which were described by the authors of ref. 20-22 are, in fact, 4-(3,5-dimethyl-1H-pyrazol-4-yl)-5- $R$-1,3-dihydro- $2 H$ imidazol-2-ones. We note that in our experiments we did not observe the formation of a cyclic product in the reaction of compound $\mathbf{6 a}$ with hydrazine.

We have developed a one-pot three component process for the synthesis of functionalized 3,4dihydropyrimidin-2-ones or imidazolin-2-ones from readily available 2,4-pentanedione, arylglyoxal hydrates, and ureas. The influence of the substituent in the arylglyoxal molecules on the course of the cyclization reaction is analyzed, allowing us to carry out regioselective syntheses of pyrimidine or imidazole rings. It is shown that the acetylacetone fragment in position 4 easily reacts with hydrazine, forming a pyrazole ring.

\section{Experimental Section}

General. IR spectra were recorded by a diffuse reflectance measurement of samples dispersed in $\mathrm{KBr}$ powder with Agilent Technologies Cary 630 spectrometer. ${ }^{1} \mathrm{H}$ NMR spectra were measured by a Varian VX-Mercury $200 \mathrm{MHz}$ spectrometer in DMSO- $\mathrm{d}_{6}$ with chemical shift $(\delta)$ given in parts per million relative to TMS as internal standard. ${ }^{13} \mathrm{C}$ NMR spectra were obtained with Varian MR-400 (100 MHz) spectrometer. The chemical shift values are reported in parts per million relative to the standard chemical shift for DMSO- $\mathrm{d}_{6}$. Mass-spectrometry was acquired on Hewlett-Packard LC/MSD 1100. Elemental analysis was carried out on EA 3000 Eurovector. Melting points were determined on the Kofler table. The reaction monitoring was accomplished by thin-layer chromatography (TLS), performed on Silufol UV-254 plates in the following systems: PhMe - EtOAc, 1:2.

General procedure for 5-acetyl-4-aroyl-6-methyl-3,4-dihydropyrimidin-2(1H)-ones (6a-d) and 5-substituted $(Z)$-4-(2-hydroxy-4-oxopent-2-en-3-yl-1,3-dihydro-2H-imidazol-2-ones (7b-e). A mixture of acetylacetone $3(1 \mathrm{mmol})$, the appropriate arylglyoxals $4 \mathbf{4 a - g}(1 \mathrm{mmol})$ and urea $5 \mathbf{a}(1 \mathrm{mmol})$ in $5 \mathrm{ml}$ of EtOH with a small amount of acetic acid (5-6 drops) was heated at reflux with stirring for 3 hours. The reaction mixture was cooled and the precipitate was filtered off, the product was washed with EtOH, and recrystallized.

5-Acetyl-4-benzoyl-6-methyl-3,4-dihydropyrimidin-2(1H)-one (6a). Yield 60\% (0.16 g), white crystals, mp 193-194 ${ }^{\circ} \mathrm{C}$ (from EtOH). (lit. ${ }^{19} \mathrm{mp} \mathrm{192-194}{ }^{\circ} \mathrm{C}$ ). ${ }^{1} \mathrm{H}$ NMR $(200 \mathrm{MHz}$, DMSO-d $\left.d_{6}\right): \delta_{\mathrm{H}} 2.16\left(3 \mathrm{H}, \mathrm{s}, \mathrm{CH}_{3}\right), 2.24\left(3 \mathrm{H}, \mathrm{s}, \mathrm{CH}_{3}\right), 5.68(1 \mathrm{H}, \mathrm{d}, 4-\mathrm{CH}, J 3.4 \mathrm{~Hz}), 7.46-7.53$ (3H, m, H-3,4,5, H Ar), 7.59 (1H, bs, 3-NH), 7.96 (2H, d, H-2,6, H Ar, J 8.0 Hz), 9.22 (1H, s, 1$\mathrm{NH})$. MS (EI) $m / z(\%): 258\left(\mathrm{M}^{+}\right), 153(85), 105(100)$. Anal. Calcd for $\mathrm{C}_{14} \mathrm{H}_{14} \mathrm{~N}_{2} \mathrm{O}_{3}$ : $\mathrm{C}, 65.11 ; \mathrm{H}$, 5.46; N, 10.85; Found: C, 65.50; H, 5.62; N, $10.75 \%$. 
5-Acetyl-4-(p-ethylbenzoyl)-6-methyl-3,4-dihydropyrimidin-2(1H)-one $\quad(6 b) . \quad$ Yield $\quad 64 \%$ (0.18 g), white crystals, mp 182-184 ${ }^{\circ} \mathrm{C}$ (from EtOH). IR (KBr): 3342, 3287, 3122, 1715, 1675, $1613,1354,1209,1138,1004 \mathrm{~cm}^{-1} .{ }^{1} \mathrm{H}$ NMR $\left(200 \mathrm{MHz}, \mathrm{DMSO}-d_{6}\right): \delta_{\mathrm{H}} 1.19\left(3 \mathrm{H}, \mathrm{t}, \mathrm{CH}_{3}, J 7.6\right.$ $\mathrm{Hz}), 2.16\left(3 \mathrm{H}, \mathrm{s}, \mathrm{CH}_{3}\right), 2.24\left(3 \mathrm{H}, \mathrm{s}, \mathrm{CH}_{3}\right), 2.62\left(2 \mathrm{H}, \mathrm{q}, \mathrm{CH}_{2}, J 7.6 \mathrm{~Hz}\right), 5.66(1 \mathrm{H}, \mathrm{d}, 4-\mathrm{CH}, J 3.4$ $\mathrm{Hz}), 7.34(2 \mathrm{H}, \mathrm{d}, \mathrm{H}-3,5, \mathrm{H} \mathrm{Ar}, J 8.0 \mathrm{~Hz}), 7.68(1 \mathrm{H}, \mathrm{bs}, 3-\mathrm{NH}), 7.90(2 \mathrm{H}, \mathrm{d}, \mathrm{H}-2,6, \mathrm{H} \mathrm{Ar}, J 8.0$ $\mathrm{Hz}), 9.21(1 \mathrm{H}, \mathrm{s}, 1-\mathrm{NH})$. MS (EI) $\mathrm{m} / z: 286\left(\mathrm{M}^{+}\right), 153(78), 133$ (100)/ Anal. Calcd for $\mathrm{C}_{16} \mathrm{H}_{18} \mathrm{~N}_{2} \mathrm{O}_{3}$ : C, 67.12; H, 6.34; N, 9.78; Found: C, 67.41; H, 6.48; N, $9.88 \%$.

Crystals of $\mathbf{6 b}\left(\mathrm{C}_{16} \mathrm{H}_{18} \mathrm{~N}_{2} \mathrm{O}_{3}, \mathrm{M}_{\mathrm{r}}=286.32\right)$ are triclinic, $\mathrm{P} 1, a=7.4759(5), b=8.0811(6), c=$ 13.4871(10) $\AA, \alpha=80.501(6)^{\circ}, \beta=85.433(6)^{\circ}, \gamma=65.824(7)^{\circ}, V=733.08(9) \AA^{3}, Z=2, d_{\text {calc }}=$ $1.297 \mathrm{~g} / \mathrm{cm}^{3}, \mu\left(\mathrm{MoK}_{\alpha}\right)=0.091 \mathrm{~mm}^{-1}, \mathrm{~F}(000)=304.7785$ reflections (4625 independent, $\mathrm{R}_{\mathrm{int}}=$ 0.032) were collected on an «Xcalibur-3» diffractometer at room temperature $\left(\mathrm{MoK}_{\alpha}\right.$ radiation, CCD-detector, graphite monochromator, $\omega$-scanning, $2 \theta_{\max }=60^{\circ}$ ). Structure was solved by direct methods and refined against $F^{2}$ within anisotropic approximation for all non-hydrogen atoms by full-matrix least squares procedure using OLEX2 program package ${ }^{24}$ with SHELXS and SHELXL modules ${ }^{25}$. All $\mathrm{H}$ atoms were placed in idealized positions and constrained to ride on their parent atoms, with $\mathrm{U}_{\text {iso }}=1.2 \mathrm{U}_{\text {eq }}\left(1.5 \mathrm{U}_{\text {eq }}\right.$ for methyl groups). $\mathrm{C}(12)-\mathrm{C}(15)$ and $\mathrm{C}(15)-\mathrm{C}(16)$ bonds were restrained to have fixed values of $1.500 \AA$ and $1.540 \AA$, respectively, to within 0.005 $\AA$. Final refinement was converged at $\mathrm{wR}_{2}=0.300$ for all 4268 reflections, $\mathrm{R}_{1}=0.085$ for 2003 reflections with $\mathrm{F}>4 \sigma(\mathrm{F}), \mathrm{S}=0.97$. Atom coordinates and crystallographic parameters have been deposited to the Cambridge Crystallographic Data Centre (CCDC 1428949). These data can be obtained free of charge via www.ccdc.cam.ac.uk/data_request/cif.

5-Acetyl-4-(p-bromobenzoyl)-6-methyl-3,4-dihydropyrimidin-2(1H)-one (6c). Yield 67\% $(0.23 \mathrm{~g})$, white crystals, mp $226-228{ }^{\circ} \mathrm{C}$ (from EtOH). ${ }^{1} \mathrm{H}$ NMR $\left(200 \mathrm{MHz}, \mathrm{DMSO}-d_{6}\right): \delta_{\mathrm{H}} 2.17$ $\left(3 \mathrm{H}, \mathrm{s}, \mathrm{CH}_{3}\right), 2.24\left(3 \mathrm{H}, \mathrm{s}, \mathrm{CH}_{3}\right), 5.65(1 \mathrm{H}, \mathrm{d}, 4-\mathrm{CH}, J 3.4 \mathrm{~Hz}), 7.74(3 \mathrm{H}, \mathrm{m}, \mathrm{H}-3,5, \mathrm{H} \mathrm{Ar}+3-\mathrm{NH})$, $7.92(2 \mathrm{H}, \mathrm{d}, \mathrm{H}-2,6, \mathrm{H}$ Ar, J $8.0 \mathrm{~Hz}), 9.26(1 \mathrm{H}, \mathrm{s}, 1-\mathrm{NH})$. Anal. Calcd for $\mathrm{C}_{14} \mathrm{H}_{13} \mathrm{BrN}_{2} \mathrm{O}_{3}$ : C, 49.87; H, 3.89; N, 8.31; Found: C, 49.70; H, 3.68; N, 8.65\%.

5-Acetyl-4-(p-fluorobenzoyl)-6-methyl-3,4-dihydropyrimidin-2(1H)-one (6d). Yield 59\% $(0.16 \mathrm{~g})$, white crystals, mp $216-218{ }^{\circ} \mathrm{C}$ (from EtOH). ${ }^{1} \mathrm{H}$ NMR (200 MHz, DMSO- $\left.d_{6}\right): \delta_{\mathrm{H}} 2.16$ $\left(3 \mathrm{H}, \mathrm{s}, \mathrm{CH}_{3}\right), 2.24\left(3 \mathrm{H}, \mathrm{s}, \mathrm{CH}_{3}\right), 5.66(1 \mathrm{H}, \mathrm{d}, 4-\mathrm{CH}, J 3.4 \mathrm{~Hz}), 7.32(2 \mathrm{H}, \mathrm{dd}, \mathrm{H}-3,5, \mathrm{H}$ Ar, $J 8.0$ $\left.\mathrm{Hz}, J_{\mathrm{H}-\mathrm{F}} 7.9\right), 7.67(1 \mathrm{H}, \mathrm{bs}, 3-\mathrm{NH}), 7.03\left(2 \mathrm{H}, \mathrm{dd}, \mathrm{H}-2,6, \mathrm{H} \mathrm{Ar}, J 8.0 \mathrm{~Hz}, J_{\mathrm{H}-\mathrm{F}} 5.5 \mathrm{~Hz}\right), 9.23(1 \mathrm{H}, \mathrm{s}$, 1-NH). Anal. Calcd for $\mathrm{C}_{14} \mathrm{H}_{13} \mathrm{FN}_{2} \mathrm{O}_{3}$ : C, 60.87; H, 4.74; N, 10.14; Found: C, 60.69; H, 4.68; N, $10.24 \%$.

(Z)-4-(2-Hydroxy-4-oxopent-2-en-3-yl)-5-phenyl-1,3-dihydro-2H-imidazol-2-one (7a). A mixture of acetylacetone $3(1 \mathrm{mmol})$, arylglyoxal 4a, urea $\mathbf{5 a}(1 \mathrm{mmol})$, and $\mathrm{FeCl}_{3}(0.05 \mathrm{mmol})$ in $10 \mathrm{ml}$ of $\mathrm{i}-\mathrm{PrOH}$ was reflux with stirring for 3 hours (indicated by TLC). The reaction mixture was cooled and the product $\mathbf{6 a}$ was filtered off, washed with EtOH. The solvent was removed under vacuum and the products $7 \mathbf{a}$ were purified by recrystallization in EtOH. Yield $65 \%(0.17$ g), pale yellow crystals, mp 212-214 ${ }^{\circ} \mathrm{C}$ (from EtOH). (lit. ${ }^{20} \mathrm{mp} 212-214{ }^{\circ} \mathrm{C}$; lit. ${ }^{20}$ str. 6a). ${ }^{1} \mathrm{H}$ NMR (200 MHz, DMSO- $\left.d_{6}\right): \delta_{\mathrm{H}} 1.92\left(6 \mathrm{H}, \mathrm{s}, 2 \mathrm{CH}_{3}\right), 7.16-7.20(1 \mathrm{H}, \mathrm{m}, \mathrm{H}-4, \mathrm{H} \mathrm{Ar}), 7.22-7.34$ 
(4H, m, H-2,3,5,6 H Ar), $10.06(1 \mathrm{H}, \mathrm{s}, \mathrm{NH}), 10.58(1 \mathrm{H}, \mathrm{s}, \mathrm{NH}), 16.82(1 \mathrm{H}, \mathrm{bs}, \mathrm{OH})$. Anal. Calcd for $\mathrm{C}_{14} \mathrm{H}_{14} \mathrm{~N}_{2} \mathrm{O}_{3}$ : $\mathrm{C}, 65.11 ; \mathrm{H}, 5.46 ; \mathrm{N}, 10.85$; Found: $\mathrm{C}, 65.33 ; \mathrm{H}, 5.35 ; \mathrm{N}, 10.66 \%$.

(Z)-4-(2-Hydroxy-4-oxopent-2-en-3-yl)-5-(4-nitrophenyl)-1,3-dihydro-2H-imidazol-2-one (7b). Yield 70\% (0.21 g), yellow crystals, mp 195-196 ${ }^{\circ} \mathrm{C}$ (from EtOH). (lit. ${ }^{20} \mathrm{mp} \mathrm{195-197}{ }^{\circ} \mathrm{C}$; lit. ${ }^{20}$ str. 6, $\left.\mathrm{R}=\mathrm{C}_{6} \mathrm{H}_{4} \mathrm{NO}_{2}-p\right)$. ${ }^{1} \mathrm{H} \mathrm{NMR}\left(200 \mathrm{MHz}, \mathrm{DMSO}-d_{6}\right): \delta_{\mathrm{H}} 1.94\left(6 \mathrm{H}, \mathrm{s}, 2 \mathrm{CH}_{3}\right), 7.57(2 \mathrm{H}$, d, H-3,5, H Ar, J 8.0 Hz), 8.18 (2H, d, H-2,6, H Ar, J $8.0 \mathrm{~Hz}), 10.45(1 \mathrm{H}, \mathrm{s}, \mathrm{NH}), 10.78(1 \mathrm{H}, \mathrm{s}$, $\mathrm{NH}), 16.90(1 \mathrm{H}, \mathrm{bs}, \mathrm{OH})$. MS (EI) $\mathrm{m} / z: 303\left(\mathrm{M}^{+}\right), 61(12 \%), 43(100 \%)$. Anal. Calcd for $\mathrm{C}_{14} \mathrm{H}_{13} \mathrm{~N}_{3} \mathrm{O}_{5}$. C, 55.45; H, 4.32; N, 13.86; Found: C, 55.40; H, 4.30; N, $13.44 \%$.

(Z)-4-(2-Hydroxy-4-oxopent-2-en-3-yl)-5-(3-fluorophenyl)-1,3-dihydro-2H-imidazol-2-one (7c). Yield 81\% (0.22 g), pale yellow crystals, mp 214-215 ${ }^{\circ} \mathrm{C}$ (from EtOH). IR (KBr): 3534, 3384, 3163, 1685, 1613, 1581, 1336, $1203 \mathrm{~cm}^{-1} .{ }^{1} \mathrm{H}$ NMR (200 MHz, DMSO- $\left.d_{6}\right): \delta_{\mathrm{H}} 1.93(6 \mathrm{H}, \mathrm{s}$, $\left.2 \mathrm{CH}_{3}\right), 6.73-7.49$ (4H, m, H-2,4,5,6, H Ar), $10.20(1 \mathrm{H}, \mathrm{s}, \mathrm{NH}), 10.68(1 \mathrm{H}, \mathrm{s}, \mathrm{NH}), 16.84(1 \mathrm{H}, \mathrm{bs}$, $\mathrm{OH}$ ). Anal. Calcd for $\mathrm{C}_{14} \mathrm{H}_{13} \mathrm{FN}_{2} \mathrm{O}_{3}$ : C, 60.87; H, 4.74; N, 10.14; Found: C, 60.40; H, 4.67; N, $10.20 \%$.

(Z)-4-(2-Hydroxy-4-oxopent-2-en-3-yl)-5-methyl-1,3-dihydro-2H-imidazol-2-one (7d). Yield $81 \%$ (0.16 g), white crystals, mp 258-260 ${ }^{\circ} \mathrm{C}$ (from EtOH). ${ }^{1} \mathrm{H}$ NMR (200 MHz, DMSO- $\left.d_{6}\right): \delta_{\mathrm{H}}$ $1.73\left(3 \mathrm{H}, \mathrm{s}, 5-\mathrm{CH}_{3}\right), 1.95\left(6 \mathrm{H}, \mathrm{s}, 2 \mathrm{CH}_{3}\right), 9.50(1 \mathrm{H}, \mathrm{s}, \mathrm{NH}), 9.82(1 \mathrm{H}, \mathrm{s}, \mathrm{NH}), 16.78(1 \mathrm{H}, \mathrm{bs}, \mathrm{OH})$. Anal. Calcd for $\mathrm{C}_{9} \mathrm{H}_{12} \mathrm{~N}_{2} \mathrm{O}_{3}$ : C, 55.09; H, 6.16; N, 14.28; Found: C, 55.14; H, 6.47; N, $14.34 \%$.

(Z)-5-(4-Fluorophenyl)-4-(2-hydroxy-4-oxopent-2-en-3-yl)-1-methyl-1,3-dihydro-2H-

imidazol-2-one (7e). Yield $61 \%(0.18 \mathrm{~g})$, pale yellow crystals, mp 234-236 ${ }^{\circ} \mathrm{C}$ (from EtOH). ${ }^{1} \mathrm{H}$ NMR (200 MHz, DMSO- $\left.d_{6}\right): \delta_{\mathrm{H}} 1.93\left(6 \mathrm{H}, \mathrm{s}, 2 \mathrm{CH}_{3}\right), 3.13\left(3 \mathrm{H}, \mathrm{s}, \mathrm{N}-\mathrm{CH}_{3}\right), 7.13-7.31(4 \mathrm{H}, \mathrm{m}, \mathrm{H}-$ 2,3,5,6, H Ar), $10.23(1 \mathrm{H}, \mathrm{s}, \mathrm{NH}), 16.71(1 \mathrm{H}, \mathrm{bs}, \mathrm{OH})$. Anal. Calcd for $\mathrm{C}_{15} \mathrm{H}_{15} \mathrm{FN}_{2} \mathrm{O}_{3}$ : C, 62.06; H, 5.21; N, 9.65; Found: C, 62.29; H, 5.47; N, $9.80 \%$.

3-Acetyl-1-(4-bromophenyl)pent-2-ene-1,4-dione (8c). A mixture of acetylacetone 3 (1.0 $\mathrm{mmol})$ and arylglyoxal $4 \mathrm{c}(1.0 \mathrm{mmol})$ previously dissolved in $5 \mathrm{ml}$ of $\mathrm{EtOH}$, was stirred at reflux for $1.5 \mathrm{~h}$. The reaction mixture was cooled. The resulting product was filtered off and washed with cold ethanol. Yield 68\% (0.20 g), pale yellow crystals, mp 120-122 ${ }^{\circ} \mathrm{C}$ (from EtOH). ${ }^{1} \mathrm{H}$ NMR (200 MHz, DMSO- $\left.d_{6}\right): \delta_{\mathrm{H}} 2.23\left(3 \mathrm{H}, \mathrm{s}, \mathrm{CH}_{3}\right), 2.51\left(3 \mathrm{H}, \mathrm{s}, \mathrm{CH}_{3}\right), 7.77(1 \mathrm{H}, \mathrm{s}, \mathrm{CH}), 7.83$ $(2 \mathrm{H}, \mathrm{d}, \mathrm{H}-2,6, \mathrm{H} \mathrm{Ar}, J 8.0 \mathrm{~Hz}), 8.01(2 \mathrm{H}, \mathrm{d}, \mathrm{H}-3,5, \mathrm{H} \mathrm{Ar}, J 8.0 \mathrm{~Hz})$. Anal. Calcd for $\mathrm{C}_{13} \mathrm{H}_{11} \mathrm{BrO}_{3}$ : C, 52.91; H, 3.76; Found: C, 52.69; H, $3.59 \%$.

1-(3-Acetyl-1-(4-bromophenyl)-1,4-dioxopentan-2-yl)urea (9c). A mixture of product 8c (1 $\mathrm{mmol})$ and urea $5 \mathrm{a}(1.0 \mathrm{mmol})$ in EtOH with a catalytic amount of acetic acid $(0.5 \mathrm{ml})$ was heated at reflux (for $40 \mathrm{~min}$.), then the mixture was cooled, the product was filtered off and recrystallized. Yield $73 \%$ (0.26 g), white crystals, mp 176-178 ${ }^{\circ} \mathrm{C}$ (from EtOH). ${ }^{1} \mathrm{H}$ NMR (200 MHz, DMSO- $\left.d_{6}\right): \delta_{\mathrm{H}} 2.19\left(3 \mathrm{H}, \mathrm{s}, \mathrm{CH}_{3}\right), 2.23\left(3 \mathrm{H}, \mathrm{s}, \mathrm{CH}_{3}\right), 4.53(1 \mathrm{H}, \mathrm{d}, \mathrm{CH}, J 7.4 \mathrm{~Hz}), 5.59-5.70$ $\left(3 \mathrm{H}, \mathrm{m}, \mathrm{NH}+\mathrm{NH}_{2}\right), 6.73(1 \mathrm{H}, \mathrm{d}, \mathrm{CH}, J 7.4 \mathrm{~Hz}), 7.54(2 \mathrm{H}, \mathrm{d}, \mathrm{H}-3,5, \mathrm{H} \mathrm{Ar}, J 8.0 \mathrm{~Hz}), 7.82(2 \mathrm{H}, \mathrm{d}$, H-2,6, H Ar, J 8.0 Hz). MS (EI) m/z: 355 (M+), 295 (25\%), 185 (50\%), 171 (100\%), 129 (73\%), 112 (65\%). Anal. Calcd for $\mathrm{C}_{14} \mathrm{H}_{15} \mathrm{BrN}_{2} \mathrm{O}_{4}$ : C, 47.34; H, 4.26; N, 7.89; Found: C, 47.55; H, 4.60; $\mathrm{N}, 7.65 \%$. 
Cyclisation of adduct 9c. A solution of $9 \mathrm{c}(1.0 \mathrm{mmol})$ in $5 \mathrm{ml} \mathrm{EtOH}$ and $1 \mathrm{ml}$ acetic acid was heated at reflux for $2.5 \mathrm{~h}$ (indicated by TCL). The mixture was cooled and $0.22 \mathrm{~g}(66 \%)$ of compound $\mathbf{6 c}$ was obtained.

General procedure for 4-(3,5-dimethyl-1H-pyrazol-4-yl)-5-phenyl-1,3-dihydro-2Himidazol-2-one (10a,b). To compound $7(1.0 \mathrm{mmol})$ previously dissolved in $5 \mathrm{ml}$ of EtOH, hydrazine $(2.0 \mathrm{mmol})$ was added and heated at reflux for $1.5 \mathrm{~h}$. The reaction mixture was cooled and the resulting product was filtered off and washed with ethanol.

4-(3,5-Dimethyl-1 $H$-pyrazol-4-yl)-5-(4-nitrophenyl)-1,3-dihydro-2 $H$-imidazol-2-one (10a). Yield $73 \%\left(0.22 \mathrm{~g}\right.$ ), orange crystals, $\mathrm{mp}>300{ }^{\circ} \mathrm{C}$ (from EtOH). $\left(\right.$ lit. ${ }^{20} \mathrm{mp} 258-260{ }^{\circ} \mathrm{C}$ ). ${ }^{1} \mathrm{H} \mathrm{NMR}$ $\left(200 \mathrm{MHz}, \mathrm{DMSO}-d_{6}\right): \delta_{\mathrm{H}} 2.05\left(6 \mathrm{H}, \mathrm{s}, 2 \mathrm{CH}_{3}\right), 7.40(2 \mathrm{H}, \mathrm{d}, \mathrm{H}-3,5, \mathrm{H} \mathrm{Ar}, J 8.0 \mathrm{~Hz}), 8.09$ (2H, d, $\mathrm{H}-2,6, \mathrm{H}$ Ar, J 8.0 Hz), 10.45 (1H, s, NH), 10.74 (1H, s, NH), 12.50 (1H, bs, NH). Anal. Calcd for $\mathrm{C}_{14} \mathrm{H}_{13} \mathrm{~N}_{5} \mathrm{O}_{3}$ : C, 56.18; H, 4.38; N, 23.40; Found: C, 56.55; H, 4.52; N, $23.60 \%$.

4-(3,5-Dimethyl-1 $H$-pyrazol-4-yl)-5-methyl-1,3-dihydro-2H-imidazol-2-one (10b). Yield $70 \%$ (0.13 g), white crystals, mp $>300{ }^{\circ} \mathrm{C}$ (from EtOH). ${ }^{1} \mathrm{H}$ NMR $\left(200 \mathrm{MHz}, \mathrm{DMSO}-d_{6}\right): \delta_{\mathrm{H}} 1.73$ $\left(3 \mathrm{H}, \mathrm{s}, \mathrm{CH}_{3}\right), 2.04\left(6 \mathrm{H}, \mathrm{s}, 2 \mathrm{CH}_{3}\right), 9.49(1 \mathrm{H}, \mathrm{s}, \mathrm{NH}), 9.70(1 \mathrm{H}, \mathrm{s}, \mathrm{NH}), 12.40(1 \mathrm{H}, \mathrm{bs}, \mathrm{NH}) .{ }^{13} \mathrm{C}$ NMR (100 MHz, DMSO-d6): $\delta_{\mathrm{C}} 10.1\left(3 \mathrm{CH}_{3}\right), 106.5\left(\mathrm{C}^{\prime}-4+\mathrm{C}-4\right), 109.3(\mathrm{C}-5), 113.6\left(\mathrm{C}^{\prime}-3+\mathrm{C}^{\prime}-5\right)$, $154.4(\mathrm{C}=\mathrm{O})$. Anal. Calcd for $\mathrm{C}_{9} \mathrm{H}_{12} \mathrm{~N}_{4} \mathrm{O}$ : C, 56.24; H, 6.29; N, 29.15; Found: C, 56.39; H, 6.48; N, $29.43 \%$.

\section{References}

1. Kappe, C. O.; Fabian, W. M. F.; Semones, H. A. Tetrahedron 1997, 53, 2816. http://dx.doi:10.1016/S0040-4020(97)00022-7

2. Kappe, C. O. Bioorg. Med. Chem. Lett. 2000, 10, 49. http://dx.doi:10.1016/S0960-894X(99)00572-7

3. Atwal, K. S.; Swanson, B. N.; Unger, S. E.; Floyd, D. M.; Moreland, S.; Hedberg, A.; O'Reilly, B. C. J. Med. Chem. 1991, 34, 806.

http://dx.doi:10.1021/jm00106a048

4. Haggarty, S. J.; Mayer, T. U.; Miyamoto, D. T.; Fathi, R.; King, R. W.; Mitchison, T. J.; Schreiber, S. L. Chem. Biol. 2000, 7, 275.

http://dx.doi:10.1016/S1074-5521(00)00101-0

5. Lacotte, P.; Puente, C.; Ambroise, Y. Chem. Med. Chem. 2013, 8, 104.

http://dx.doi:10.1002/cmdc.201200417

6. Biginelli, P. Gazz. Chim. Ital. 1893, 23, 360.

7. Kappe, C. O. Acc. Chem. Res. 2000, 33, 879. http://dx.doi:10.1021/ar000048h

8. Byk, G.; Kabha, E. J. Comb. Chem. 2004, 6, 596.

http://dx.doi:10.1021/cc049962i 
9. Mabry, J.; Ganem, B. Tetrahedron Lett. 2006, 47, 55.

http://dx.doi:10.1016/j.tetlet.2005.10.124

10. Quan, Z.; Zhang, Z.; Da, Y.; Wang, X. Chin. J. Org. Chem. 2009, 29, 876. http://dx.doi:abstract328201

11. Jindal, R.; Bajaj, S. Curr. Org. Chem. 2008, 12, 836. http://dx.doi:10.2174/138527208784911842

12. Saini, A.; Kumar, S.; Sandhu, J. S. J. Indian Chem. Soc. 2007, 84, 959. http://www.worldcat.org/title/review-biginellireaction/oclc/184980076\&referer=brief results

13. Schnell, B.; Krenn, W.; Faber, K.; Kappe, C. O. J. Chem. Soc., Perkin Trans. 1 2000, 4382. http://dx.doi:10.1039/B006372J

14. Lu, J.; Bai, Y. Synthesis 2002, 466. http://dx.doi:10.1055/s-2002-20956

15. Roy, S. R.; Jadhavar, P. S; Seth, K.; Sharma, K. K.; Chakraborti, A. K. Synthesis 2011, 2261. http://dx.doi:10.1055/s-0030-1260067

16. Xu, D-Z.; Li, H.; Wang, Y. Tetrahedron 2012, 68, 7867. http://dx.doi:10.1016/j.tet.2012.07.027

17. Liberto, A. N.; de Paiva Silva, S.; de Fátima, A.; Fernandes, S. A. Tetrahedron 2013, 69, 8245. http://dx.doi:10.1016/j.tet.2013.07.024

18. Singh, Kamaljit; Singh, Kawaljit; Kaur, Hardeep Tetrahedron 2012, 68, 6169. http://dx.doi:10.1016/j.tet.2012.05.073

19. Balalaie, S.; Soleiman-Beigi, M.; Rominger, F. J. Iran. Chem. Soc. 2005, 2, 319. http://dx.doi:10.1007/BF03245937

20. Karami, B.; Akrami, S.; Khodabakhshi, S.; Rahmatzadeh S. Arkivoc 2013, (iv), 323. http://dx.doi:arkivoc/2013/4/

21. Karami, B.; Khodabakhshi, S.; Akrami, S.; Farahi M. Tetrahedron Lett. 2014, 55, 3581. http://dx.doi:10.1016/j.tetlet.2014.02.025

22. Karami, B.; Akrami, S.; Khodabakhshi, S.; Rahmatzadeh S. Bull. Korean Chem. Soc. 2013, $34,3677$. http://dx.doi:10.5012/bkes.2013.34.12.3677

23. Ryabukhin, S. V.; Plaskon, A. S.; Ostapchuk, E. N.; Volochnyuk, D. M.; Tolmachev, A. A. Synthesis 2007, 417. http://dx.doi:10.1055/s-2007-965881

24. Dolomanov, O.; Bourhis, L.; Gildea, R. J. Appl. Cryst. 2009, 42, 339. http://dx.doi:10.1107/S0021889808042726

25. Sheldrick, G. M. Acta Crystallogr. 2008, A64, 112. http://dx.doi:10.1107/S0108767307043930 